\title{
The effects of a diet low in hay and high in flaked maize on milk-fat secretion and on the concentrations of certain constituents in the blood plasma of the cow
}

\author{
BY J. E. STORRY AND J. A. F. ROOK \\ National Institute for Research in Dairying, Shinfield, Reading \\ (Received Io August 1964-Accepted 26 October 1964)
}

\begin{abstract}
The original observations of Powell (1938, 1939, I94I) that, for lactating cows, diets containing only a small amount of roughage, or usual amounts of roughage offered in a finely ground form, are frequently associated with an unusually low content of fat in the milk have been fully confirmed (see Van Soest (1963) for a comprehensive review). Information on the associated changes in the composition of the milk fat is, however, incomplete. The few studies in which changes in the fatty acid composition have been measured by chromatographic techniques (Smith \& Ronning, 196r ; Brown, Stull \& Stott, I962; King \& Hemken, 1962; Palmquist, Smith \& Ronning, I964) agree generally in showing an increase in the proportion of unsaturated acids when diets contain little roughage, but the reported effects on the other acids are inconsistent and in much of the work all the acids were not investigated. There is also still much uncertainty as to the cause of the fall in milk fat content (Van Soest, 1963; Rook \& Storry, I964). The experiments now described were therefore done to obtain additional information on the effect of a diet low in hay and high in flaked maize on the secretion in milk of the component fatty acids of milk fat and on the concentrations in blood plasma of several constituents that are possibly of importance in milk fat synthesis.
\end{abstract}

\section{EXPERIMENTAL}

Animals and their management. Two Friesian cows, Brilliant 2 and Glee 6 in their 2nd and $4^{\text {th }}$ months respectively of lactation, were selected from the Institute herd. They were housed in metabolism stalls and for a preliminary period of 15 days were offered a control diet of $7 \mathrm{~kg}$ of meadow hay and I $2 \mathrm{~kg}$ (Brilliant 2) or I I $\mathrm{kg}$ (Glee 6) of dairy concentrate cubes. After a further 6 (Glee 6 ) or 8 (Brilliant 2) days on the control diet, the amounts of hay and of cubes were then progressively reduced and replaced by a roughly equivalent amount (in terms of starch equivalent) of flaked maize until a marked reduction in milk fat content was established. An abrupt return to the original diet followed and the animals were given this diet until the original fat content in the milk was reached. With both cows there were irregular refusals of the flaked maize, and after the return to the original diet of hay and concentrate cubes some hay was refused over a period of up to ro days. Full details of the foods consumed are given in Figs. I and 2.

Sampling and methods of analysis. Milk yield was recorded and samples of milk 
were taken at each milking. Daily composite samples were prepared and analysed for fat content by the Gerber method (British Standards Institution, I955). At regular intervals throughout the experiment weighted composite samples representing the milk secreted over 2 days were also prepared and analysed for the fatty acid composition of the milk fat by gas chromatography (Storry \& Rook, I965).

Samples of blood were taken from the jugular vein through an indwelling Polythene cannula, that had been inserted some days previously, at $9.00,12.00$ and $15.00 \mathrm{~h}$ on certain days at intervals throughout the experiment. Ice-cold, trichloroacetic acid filtrates of whole blood for the determination of lactic acid (Barker \& Summerson, I94I; Pennington \& Sutherland, 1956), methanol-chloroform (I:2, v/v) extracts of plasma for the determination of lipids and samples of plasma for the determination of volatile fatty acids (Storry \& Rook, r965) glucose (Somogyi, I952) and ketone bodies (Reid, r960) were prepared and stored for analysis as already described (Storry \&. Rook, 1965 ).

\section{RESULTS}

\section{Milk yield and composition}

Milk yield (Figs. I and 2). The replacement of hay and concentrate cubes in the diet by flaked maize was adjusted to maintain or slightly to increase the total starch equivalent of the daily diet and, consistent with this, the milk yield of Brilliant 2 showed only a slow decline throughout the period of the experiment. The milk yield of Glee 6 , however, fell noticeably from the $2 \mathrm{rst}$ day to the 38 th day of the experiment, when the diet offered provided only $2 \mathrm{~kg}$ of hay and $8 \mathrm{~kg}$ of flaked maize, and recovered on the reintroduction of the control diet.

Fat content (Figs. I and 2). Both cows maintained the original fat content, of $4^{\circ}-4.5 \%$, throughout the initial stages of the changeover from the control diet, and in fact the fat content of the milk of Glee 6 tended to increase up to day 24 when the daily ration of hay had been reduced to $\mathrm{I} \mathrm{kg}$ and that of flaked maize increased to $5 \mathrm{~kg}$. Thereafter the fat content fell sharply but irregularly, over a period of 8-1o days to a minimum value of about $1.5 \%$ for both cows. On the abrupt return of the cows to the control diet, the fat content did not recover immediately but increased progressively to the original value over a period of 2-3 weeks.

Fat composition (Table $\mathbf{r}$ ). With the depression in the fat content of the milk there were large decreases in the relative amounts of the major saturated acids and corresponding increases in the unsaturated acids. The proportions of the cis- and transisomers of octadecenoic acid in the milk fat varied with the amount of flaked maize in the diet. The proportion of the trans-acid (elaidic or trans-vaccenic acid) increased in both cows from a value of about $10 \%$ of the total octadecenoic acid on the control diet to a maximum of about $50 \%$ on the diet low in hay and high in flaked maize. The same phenomenon has previously been observed in the milk fat of cows offered a diet low in hay and high in concentrates supplemented with cottonseed oil (Moore \& Williams, I963). The fatty acids of cottonseed oil and, to a lesser extent, of flaked maize are rich in linoleic acid, and it seems probable that on low-roughage diets, when 
the normal processes of hydrogenation may be less complete, the linoleic acid is converted in the rumen partially into the trans-isomers of octadecenoic acid.

Fatty acid yields (Figs. I and 2). The falls in fat percentage were the result of a reduced secretion of all the major component fatty acids of milk fat, although the fall

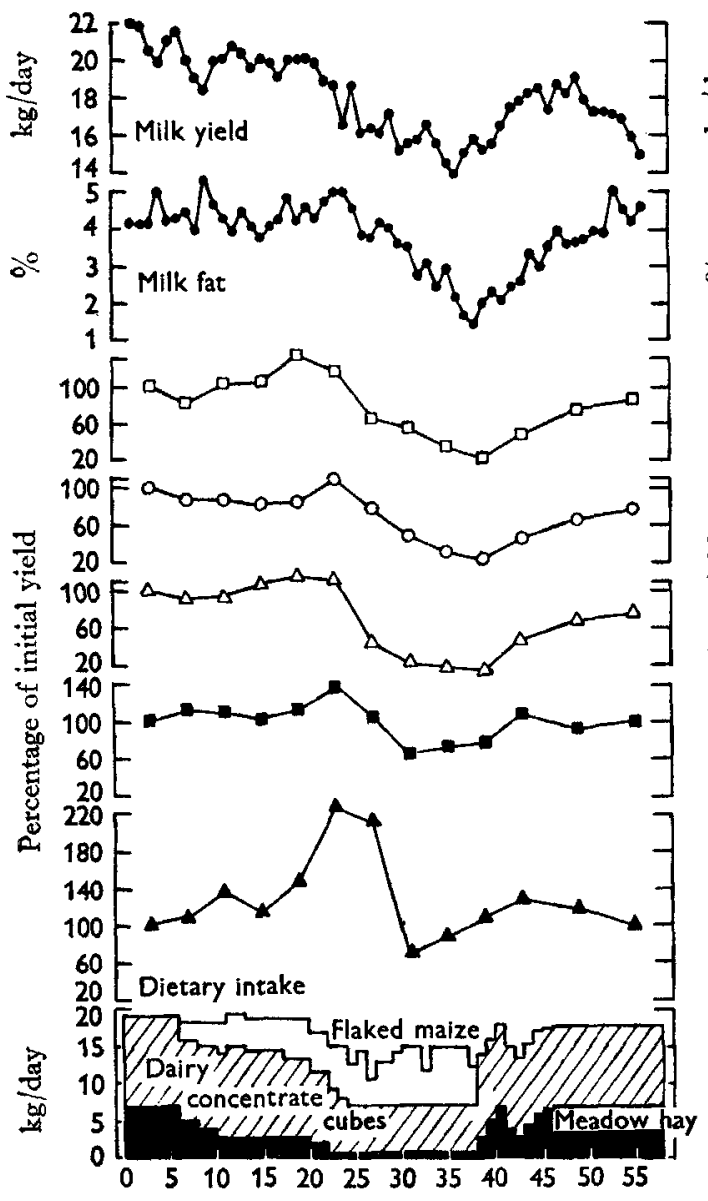

Days on experiment

Fig. I

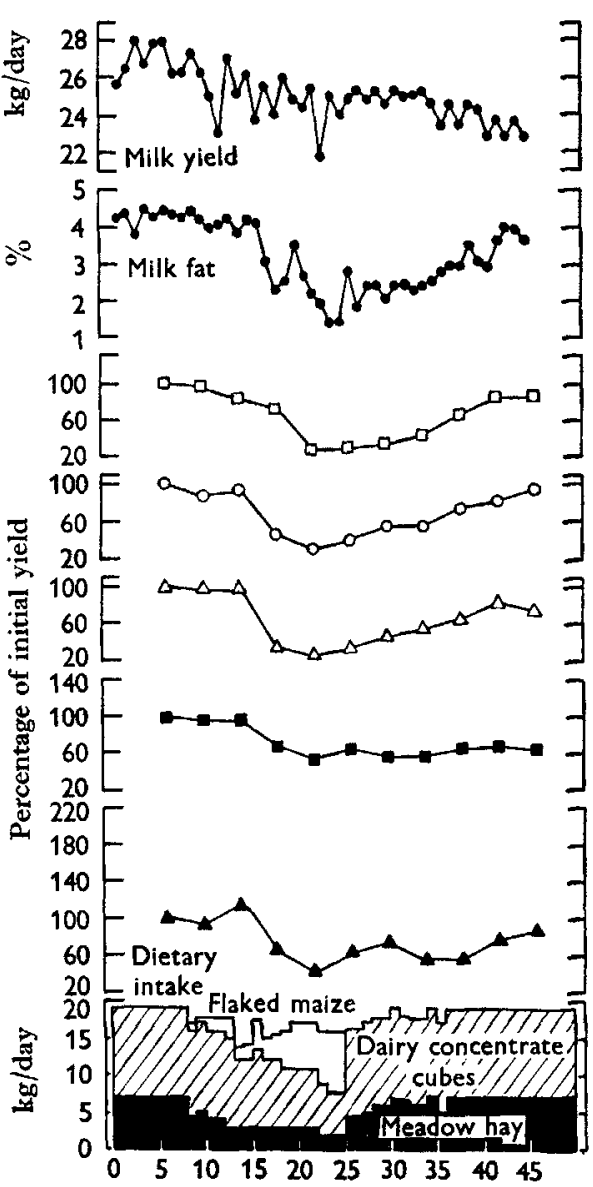

Days on experiment

Fig. 2

Fig. $x$. Variations with diet, for cow Glee 6, in the yield of milk, in milk fat content and in the yield of individual fatty acids of milk fat $\left(\square-\square, C_{1}-C_{10}\right.$ acids; $O-0$, palmitic acid; $\Delta-\Delta$, stearic acid; $\boldsymbol{\square - \boldsymbol { n }}$, oleic acid; $\boldsymbol{\Delta}-\boldsymbol{\Delta}$, linoleic + linolenic acids).

Fig. 2. Variations with diet, for cow Brilliant 2, in the yield of milk, in milk fat content and in the yield of individual fatty acids of milk fat $\left(\square-\square, C_{4}-C_{10}\right.$ acids; $\mathrm{O}-\mathrm{O}$, palmitic acid; $\triangle-\triangle$, stearic acid; $\mathbf{\square}-\mathbf{Z}$, oleic acid; $\mathbf{\Delta}-\mathbf{\Lambda}$, linoleic + linolenic acids).

was less marked with oleic acid and with linoleic acid plus linolenic acid than with the other acids. For Glee 6 the yields of all the major acids from butyric acid up to and including stearic acid were reduced to about $20 \%$ of the original yield, whereas the yields of oleic acid and linoleic plus linolenic acids were reduced to about $70 \%$. A 
more marked fall in the yields of oleic acid and linoleic plus linolenic acids, but still relatively less than that of other acids, was observed for Brilliant 2, but a part of this fall appeared to be the result of a lactational trend, since the yields of these acids recovered only partially in spite of the recovery of milk fat content to its initial value. The slight increase in fat content of the milk of Glee 6 in the early stages of the change of diet was associated with a twofold increase in the yield of linoleic acid plus linolenic acid.

Table I. Effect of a low-hay, high-flaked maize diet on the percentage fatty acid composition of milk fat of two cows

\begin{tabular}{|c|c|c|c|c|}
\hline \multirow[b]{2}{*}{ Fatty acid* } & \multicolumn{2}{|c|}{ Brilliant 2} & \multicolumn{2}{|c|}{ Glee 6} \\
\hline & $\begin{array}{l}\text { Control diet } \\
\text { (days } 5 \text { and } 6 \text { ) }\end{array}$ & $\begin{array}{l}\text { Experimental diet } \\
\text { (days } 21 \text { and 22) }\end{array}$ & $\begin{array}{l}\text { Control diet } \\
\text { (days } 3 \text { and } 4 \text { ) }\end{array}$ & $\begin{array}{l}\text { Experimental diet } \\
\text { (days } 35 \text { and } 36 \text { ) }\end{array}$ \\
\hline $4: 0$ & 4.4 & $2 \cdot 6$ & $3 \cdot 8$ & $2 \cdot 3$ \\
\hline $6: 0$ & $2 \cdot 8$ & $I \cdot 5$ & $2 \cdot 8$ & $I \cdot 4$ \\
\hline $8: 0$ & $1 \cdot 7$ & $I \cdot 0$ & $I \cdot 3$ & 0.7 \\
\hline 9:0 & 0.2 & $O \cdot I$ & 0.2 & 0.2 \\
\hline $10: 0$ & $2 \cdot 0$ & $\mathbf{I} \cdot 7$ & 3.0 & $I \cdot 9$ \\
\hline II:O & 0.3 & 0.4 & 0.5 & 0.4 \\
\hline $12: 0\}$ & & & & \\
\hline $12: 1\}$ & $3 \cdot 0$ & $2 \cdot 0$ & 4.2 & $2 \cdot 8$ \\
\hline $14: 0$ & $I I \cdot I$ & $7 \cdot 9$ & $\mathrm{II} \cdot 8$ & $7 \cdot 2$ \\
\hline $14: 1$ & $I \cdot 0$ & $I \cdot 7$ & $I \cdot I$ & $\mathrm{I} \cdot 5$ \\
\hline I 5:0 br & 0.4 & $0: 4$ & 0.5 & 0.5 \\
\hline $\left.\begin{array}{l}\text { I5:0? } \\
\text { I } 6: 0 \mathrm{br}\end{array}\right\}$ & 0.6 & $I \cdot 4$ & 0.7 & $x \cdot 8$ \\
\hline $16: 0$ & $31 \cdot 8$ & $25 \cdot 6$ & $35 \cdot I$ & $22 \cdot 9$ \\
\hline $16: 1$ & $\mathrm{I} \cdot 8$ & 3.5 & $1 \cdot 4$ & $3 \cdot 1$ \\
\hline $\left.\begin{array}{l}17: 0 \\
18: 0 \mathrm{br} ?\end{array}\right\}$ & 0.4 & 0.6 & 0.4 & 0.9 \\
\hline $17: 0$ & 0.8 & 0.9 & 0.7 & $x \cdot 6$ \\
\hline $18: 0$ & $8 \cdot 2$ & $6 \cdot 1$ & 9.0 & $3 \cdot 8$ \\
\hline 18: I cis & $23 \cdot 2$ & 20.8 & 18.9 & $2 \mathrm{I} \cdot 8$ \\
\hline I8: I trans & $3 \cdot 2$ & 19.6 & $3 \cdot 1$ & 19.2 \\
\hline $\left.\begin{array}{l}18: 2 \\
r 8: 3\end{array}\right\}$ & $2 \cdot 5$ & $3 \cdot 3$ & $2 \cdot I$ & $5 \cdot 5$ \\
\hline
\end{tabular}

* Number of carbon atoms and number of double bonds (Farquhar, Insull, Rosen, Stoffel \& Ahrens, 1959).

\section{Blood composition}

Daily mean values for the concentrations of the various blood constituents are presented graphically in Figs. 3 and 4 .

Volatile fatty acids. The concentration of acetate decreased markedly with the introduction of large amounts of flaked maize into the diet and the reduction of the amount of hay. 'The changes in concentration throughout the experiments were, however, much more closely related to the changes in milk fat content than to the changes of diet. With Glee 6, during the changeover from the control diet to the diet low in hay and high in flaked maize, the concentration of acetate decreased slightly for a short period and then recovered to the original level, and was maintained there until the sharp fall in fat content occurred about 3 weeks after the first change of diet. A delay in recovery of the original acetate content, which followed the pattern of 
recovery in milk fat content, after the abrupt reintroduction of the control diet was particularly noticeable with Brilliant 2.

The concentration of acetate in blood varies widely throughout a feeding interval, with a maximum usually $2-3 \mathrm{~h}$ after feeding, but the depression in concentration with

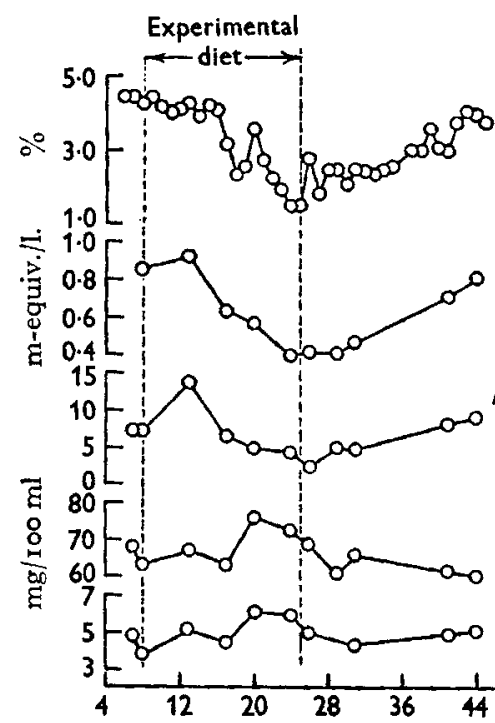

Days on experiment, Brilliant 2

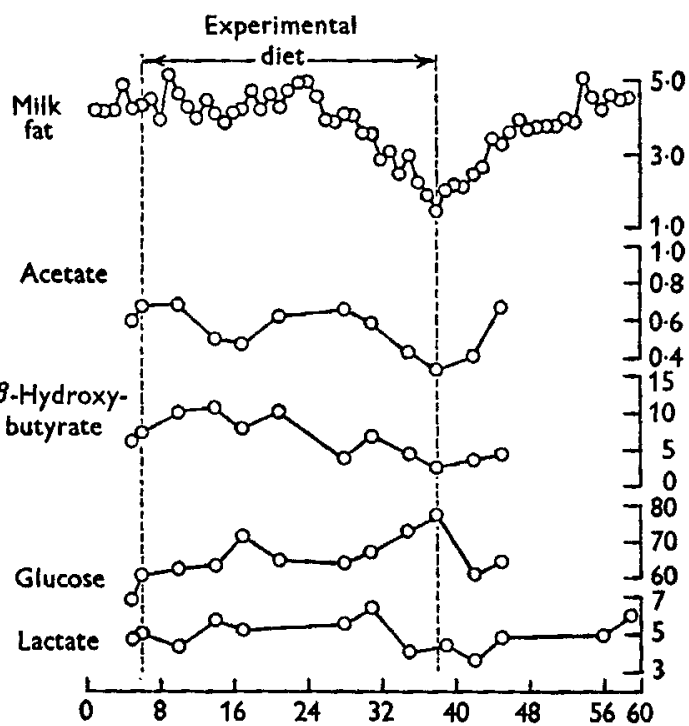

Days on experiment, Glee 6

Fig. 3. Variations in the concentration in the blood plasma of two cows of acetate, $\beta$-hydroxybutyrate, glucose and lactate in relation to observed changes in milk fat content.

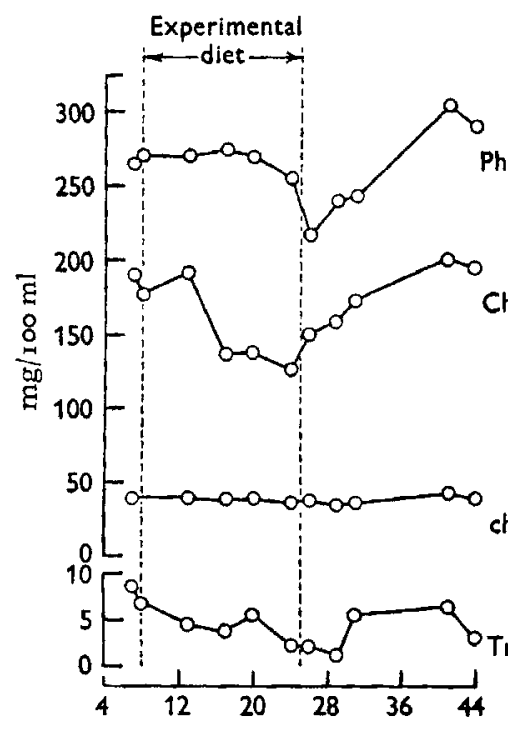

Days on experiment, Brilliant 2

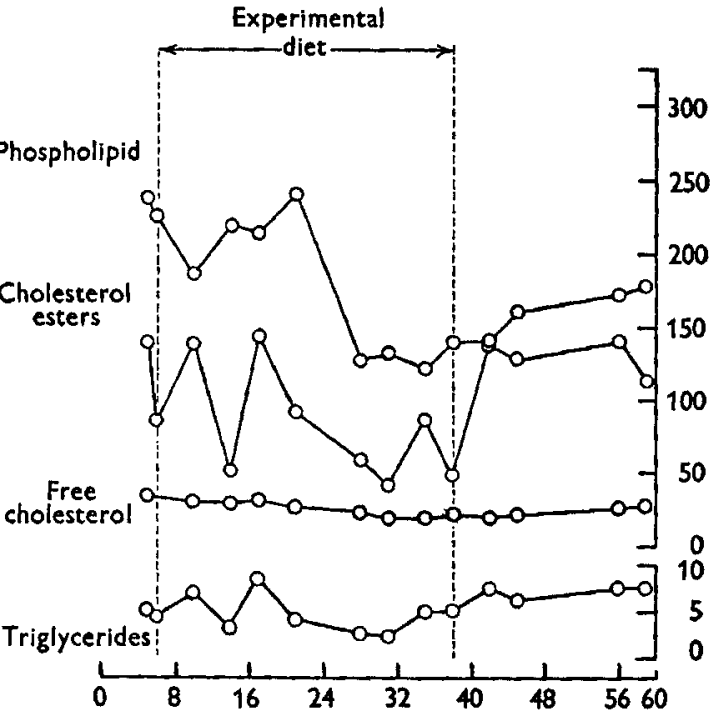

Days on experiment, Glee 6

Fig. 4. Variations in the concentration in the blood plasma of two cows of phospholipid, esterified cholesterol, free cholesterol and triglyceride with changes in diet. 
the diets low in hay and high in flaked maize was observed at all sampling times. The mean values with their standard errors for Brilliant 2 for the first 2 and last 2 days on which samples were taken were: $\mathrm{I} \cdot \mathrm{II} \pm 0.006 \mathrm{~m}$-equiv./1. at $09 \cdot 00 \mathrm{~h}, 0.76 \pm 0 \cdot 10 \mathrm{~m}$ equiv./1. at $12.00 \mathrm{~h}, 0.68 \pm 0.06 \mathrm{~m}$-equiv./1. at $15.00 \mathrm{~h}$ and for the intervening occasions the corresponding values were $0.75 \pm 0.10,0.45 \pm 0.06$ and $0.35 \pm 0.06 \mathrm{~m}$-equiv. $/ 1$.

The concentrations of propionate and butyrate were at all times low, mainly within the range of $0.0 \mathrm{r}-0.03 \mathrm{~m}$-equiv./1., but the values for propionate in the blood plasma of Glee 6 increased to a maximum of $0.05 \mathrm{~m}$-equiv. $/ 1$. when the amount of flaked maize in the diet was high.

$\beta$-Hydroxybutyrate. The initial changes of diet were associated with about a twofold increase in the concentration of $\beta$-hydroxybutyrate in blood plasma, and Glee 6 , whose fall in milk fat content was considerably delayed, maintained a high concentration until the drop in fat content occurred. Subsequently, however, with both cows and at the same time as the fall in fat content occurred, the concentration of $\beta$ hydroxybutyrate gradually decreased to about half of the initial values. As with the concentration of acetate, the concentration of $\beta$-hydroxybutyrate did not immediately recover after the reintroduction of the control diet but tended to follow the recovery in milk fat content.

Glucose. The concentration of glucose in the blood plasma of both cows increased measurably with the introduction of large amounts of flaked maize into the diet and returned to the initial levels shortly after the reintroduction of the control diet.

Lactic acid. The values for the concentration of lactic acid varied from 4 to $6 \mathrm{mg} /$ $100 \mathrm{ml}$, and for Brilliant 2 the highest values were observed when the diet contained a large amount of flaked maize.

Lipids. There was no effect of diet on the concentration of unesterified cholesterol. The concentrations of phospholipid and cholesteryl esters fell markedly towards the end of the period on the low-roughage diet and, with the exception of the phospholipid concentration of Glee 6, recovered with the reintroduction of the control diet. The concentration of triglycerides was low in the plasma of both cows, but was nevertheless depressed in association with the reduction in milk fat content.

\section{DISCUSSION}

Three components of the blood plasma have been suggested as precursors for the synthesis of the fatty acids of milk fat. They are acetate, used in the synthesis of $\mathrm{C}_{4}-\mathrm{C}_{16}$ acids (Cowie, Duncombe, Folley, French, Glascock, Massart, Peeters \& Popják, I95I; Popják, French, Hunter \& Martin, I95I; Rogers \& Kleiber, 1957; Hardwick, Linzell \& Mepham, 1963), $\beta$-hydroxybutyrate, possibly used in the synthesis of $\mathrm{C}_{4}-\mathrm{C}_{10}$ acids (Kumar, Lakshmanan \& Shaw, 1959), and the triglycerides of the low-density lipoproteins (Barry, Bartley, Linzell \& Robinson, I963; Welch, Noble, Wright, Bishop \& Glascock, 1963) used in the synthesis of long-chain acids. From early studies of the effect of low-roughage diets on milk-fat secretion (Tyznik, 195I; Balch, Balch, Bartlett, Bartrum, Johnson, Rowland \& Turner, 1955), which established a marked decrease in the concentration of acetic acid relative to that of 
propionic acid in the rumen contents of cows on low-roughage diets, it was concluded that the fall in milk fat content was the result of a reduction in the amount of acetate available for the synthesis of fatty acids. The variable recoveries in fat content of the milk of cows receiving low-roughage diets and in which milk fat content had been depressed, after the intraruminal addition of acetic acid and sodium acetate or the dietary addition of sodium acetate (Stoddard, Allen \& Peterson, 1949; Tyznik \& Allen, 195I; Balch \& Rowland, 1959), however, indicated that a shortage of acetate could not be the only factor. Consequently emphasis has since also been given (Rook, I959; Van Soest \& Allen, 1959; Shaw, 1961) to the relative increase in the concentration of propionic acid in the rumen liquor of cows on low-roughage diets, and to the effect of an increased absorption of propionic acid from the rumen on the synthesis of the fatty acids of milk fat from $\beta$-hydroxybutyrate and triglycerides of blood plasma. The antiketogenic effect of propionic acid is well recognized and, on this basis, the fall in milk fat content observed with low-roughage diets has been attributed, at least in part, to a decreased synthesis of fatty acids from $\beta$-hydroxybutyrate. The glucogenic effect of propionic acid also may be involved in the reduced fat synthesis, since Vallance \& McClymont (1959) observed, and we have confirmed (unpublished observations), that the intravenous infusion of glucose in the milking cow depresses milk fat secretion. McClymont \& Vallance (1962) later suggested that this was the result not necessarily of a reduced synthesis of fatty acids from $\beta$-hydroxybutyrate, the concentration of which in blood would be reduced by intravenous glucose infusion, but probably of a reduced synthesis from plasma triglycerides, since there was an associated decrease in the concentration of the latter in the blood plasma. In support of this possibility, we have shown that intravenous glucose infusion causes a depression in the secretion of the $\mathrm{C}_{18}$ acids of milk fat (unpublished observations) and that the intravenous infusion of a cottonseed oil emulsion increases the yield of $\mathrm{C}_{18}$ acids (Storry \& Rook, 1964).

The results now presented show that a fall in milk fat content induced by a diet low in hay and high in flaked maize is associated with a decreased secretion of all major component fatty acids but that, in comparison with other acids, the secretion of the unsaturated $\mathrm{C}_{18}$ acids is decreased to a smaller extent. These results generally confirm the more limited ones previously cited and are also consistent with increases and decreases respectively reported earlier in iodine and Reichert-Meissl values of the milk fat (McClymont, I95०; Balch, Balch, Bartlett, Cox \& Rowland, 1952; Balch et al. 1955). Also the concentrations of acetate, $\beta$-hydroxybutyrate and triglycerides in the blood plasma of both our cows were depressed, and that of glucose increased in close association with the observed depressions in milk fat content. Van Soest \& Allen (1959) have previously reported a decrease in the concentration of acetate and of ketone bodies in the blood of milking cows given a diet low in roughage, and values reported by McClymont (I95I) show a slightly lower range for the concentration of the total steam-volatile fatty acids in the blood of cows receiving a low-roughage diet than for normal cows. Plasma glucose concentrations in sheep given finely ground pelleted hay are also higher than those in sheep given chopped hay (Bensadoun, Paladines \& Reid, 1962). The observed changes in blood composition and in the 
secretion of the fatty acids of milk fat would therefore be consistent with a reduced synthesis of fatty acids by each of the three routes. We intend now to evaluate the relative importance of each of the routes by determining, in milking cows given lowroughage diets, the responses in the secretion of individual fatty acids to intraruminal additions of acetic and butyric acids and to intravenous infusions of acetate, $\beta$ hydroxybutyrate and triglycerides.

One unexplained feature of our results is that, though there is much evidence to suggest that the $\mathrm{C}_{18}$ acids of milk fat are synthesized by a common route from plasma triglycerides, the observed decrease in secretion of stearic acid was much greater than the decrease in the secretion of oleic acid and of linoleic acid plus linolenic acid. This could possibly reflect an increase in the proportion of unsaturated acids of plasma triglycerides resulting from the increased ingestion of linoleic acid with the feeding of large amounts of flaked maize, especially if under these conditions hydrogenation of dietary unsaturated acids in the rumen was less complete.

\section{SUMMARY}

r. The effects of giving a diet containing a low proportion of hay and a high proportion of flaked maize on the milk fat content, on the yields of the major component fatty acids and on the concentrations in the blood plasma of metabolites of importance in fat synthesis, have been investigated with two cows.

2. The diet caused a marked fall in the fat content of the milk from values of about $4.0 \%$ to minimum values of about $\mathrm{I} \cdot 5 \%$, and there was a diminished secretion of all the major fatty acid components of the milk fat. The falls in the yields of the $C_{18}$ unsaturated acids were less marked than those for stearic acid and the lower acids of carbon chain length $\mathrm{C}_{4}-\mathrm{C}_{16}$. Also the proportion of octadecenoic acid which was present as the trans-isomer increased from about $15 \%$ to about $50 \%$.

3 . There was a fall in the concentrations of acetate, $\beta$-hydroxybutyrate and triglyceride in the plasma, which recovered on reintroduction of the control diet. The pattern of fall and recovery of these constituents in the blood plasma followed closely that of the milk fat content.

4. The results are discussed in relation to the effect of diet on milk fat synthesis.

We thank Mr A. J. Hall, Mr B. Tuckley and Mr D. Millard for skilled technical assistance and $\mathrm{Mr} \mathrm{V}$. Johnson for care of the experimental animals.

\section{REFEREN CES}

Balch, C. C., Balch, D. A., Bartlett, S., Bartrum, M. P., Johnson, V. W., Rowland, S. J. \& 'Turner, J. (1955). F. Dairy Res. 22, 270.

Balch, C. C., Balch, D. A., Bartlett, S., Cox, C. P. \& Rowland, S. J. (1952). F. Dairy Res. I9, 39.

Balch, C. C. \& Rowland, S. J. (1959). F. Dairy Res. 26, 162.

Barker, S. B. \& Summerson, W. H. (1941). F. biol. Chem. 138, 535.

Barry, J. M., Bartley, W., Linzell, J. L. \& Robinson, D. S. (I963). Biochem. F. 89, 6.

Bensadoun, A., Paladines, O. L. \& Reid, J. T. (1962). F. Dairy Sci. 45, 1203.

British Standards Institution (1955). B.S. 696, p. 7 .

Brown, W. H., Stull, J. W. \& Stott, G. H. (1962). 7. Dairy Sci. 45, I91. 
Cowie, A. T., Duncombe, W. G., Folley, S. J., French, T. H., Glascock, R. F., Massart, L., Peeters, G. J. \& Popják, G. (I95I). Biochem. F. 49, 6ro.

Farquhar, J. W., Insull, W., Rosen, P., Stoffel, W. \& Ahrens, E. H. (1959). Nutr. Rev. 17, Suppl.

Hardwick, D. C., Linzell, J. L. \& Mepham, T. B. (1963). Biochem. F. 88, 2 I 3.

King, R. L. \& Hemken, R. W. (I962). F. Dairy Sci. 45, 1336.

Kumar, S., Lakshmanan, S. \& Shaw, J. C. (I959). F. biol. Chem. 234, 754.

McClymont, G. L. (1950). Aust. vet. $\mathscr{~} 26$, 1 I I.

McClymont, G. L. (195I). Aust. F. agric. Res. 2, 58.

McClymont, G. L. \& Vallance, S. (1962). Proc. Nutr. Soc. 21, xli.

Moore, J. H. \& Williams, D. L. (1963). Rep. nat. Inst. Dairy., Reading, p. 128.

Palmquist, D. L., Smith, L. M. \& Ronning, M. (I964). F. Dairy Sci. 47, 5 I6.

Pennington, R. J. \& Sutherland, T. M. (1956). Biochem. F. 63, 353.

Popják, G., French, T. H., Hunter, G. D. \& Martin, A. J. P. (1951). Biochem. F. 48, 612.

Powell, E. B. (1938). Proc. Amer. Soc. Anim. Prod. 3r, 40.

Powell, E. B. (1939). F. Dairy Sci. 22, 453.

Powell, E. B. (I94I). F. Dairy Sci. 24, 504.

Reid, R. L. (1960). Analyst, 85, 265.

Rogers, T. A. \& Kleiber, M. (1957). Proc. Soc. exp. Biol., N.Y., 94, 705.

Rook, J. A. F. (1959). Proc. Nutr. Soc. 18, I17.

Rook, J. A. F. \& Storry, J. E. (1964). Chem. $\mathscr{O}^{\circ}$ Ind. p. 1778.

Shaw, J. C. (I96I). Int. Congr. Anim. Prod. virI. Hamburg, I, 29.

Smith, L. M. \& Ronning, M. (r961). F. Dairy Sci. 44, II70.

Somogyi, M. (1952). F. biol. Chem. 195, 19.

Stoddard, G. E., Allen, N. N. \& Peterson, W. H. (1949). F. Anim. Sci. 8, 630.

Storry, J. E. \& Rook, J. A. F. (r964). Biochem. F. 9I, 27 c.

Storry, J. E. \& Rook, J. A. F. (1965). Biochem. F. (In the Press.)

Tyznik, W. J. (195I). The effect of the amount and physical state of the roughage upon the rumen fatty acids and milk fat of dairy cows. Ph.D. Thesis, University of Wisconsin.

Tyznik, W. \& Allen, N. N. (195I). F. Dairy Sci. 34, 493.

Vallance, W. S., \& McClymont, G. L. (1959). Nature, Lond., r83, 466.

Van Soest, P. J. (1963). F. Dairy Sci. 46, 204.

Van Soest, P. J. \& Allen, N. N. (1959). F. Dairy Sci. 42, 1977.

Welch, V. A., Noble, R. C., Wright, E. W., Bishop, C. \& Glascock, R. F. (1963). Biochem. F. 87, 32 P. 